\title{
Mutual distrust and threats in the Middle East: Is there a chance for dialogue? ${ }^{1}$
}

\author{
Margret Johannnsen*
}

\begin{abstract}
Nuclear proliferation in the Middle East is driven by motives not essentially different from those behind the nuclear arms race of the Cold War Periode. To argue otherwise, in particular while assuming that rational behaviour with regard to developing a nuclear option and to handling a nuclear inventory is alien to the Middle East, betrays a bias counterproductive to overcoming mutual threat perceptions. When tackling the problem of nuclear proliferation we must take into account the hidden nexus between conflict regarding territory and self-determination on the one hand and the proliferation issue on the other. The author argues for a comprehensive approach that puts seemingly unconnected issues such as a nuclear-weaponsfree-zone and the Israeli-Palestinian conflict, all on the negotiating table.
\end{abstract}

Keywords: Middle East, Threat Perceptions, Nuclear Weapons, Proliferation

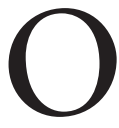
$\mathrm{n}$ a speaking tour in Germany at the peak of the Palestinian Intifada, Mustafa Barghouti - founder of the Union of Palestinian Medical Relief Committees, General Secretary of the Palestinian National Initiative (al-Mubadara al-Wataniyya al-Filistiniyy) and Information Minister in the new Palestinian cabinet - was questioned about the delivery to Israel of German submarines which experts suspect of being nuclear-capable. The acquisition of the Dolphins can be seen as providing Israel with an assured second strike capability. Barghouti was asked whether this was something he, as a Palestinian, worried about, bearing in mind that a future Palestinian state will in all probability be demilitarized or have only lightly armed security forces. Yes, he said, he did worry. Seen in the context of the Israeli-Palestinian conflict, anything that resembled Israeli invulnerability would only encourage an Israeli policy of dispossessing the Palestinians and waging war against them in violation of international law. He was convinced that in the case of Israel's occupation policy, invulnerability would promote a culture of impunity.

\section{Threat perceptions under conditions of uncertainty}

Here it is in a nutshell: Not only is there distrust and threat but the two also link a variety of issues, in this case the third tier of Israel's nuclear triade with the Israeli occupation policy. It is this linkage that I will focus on when trying to answer the question of whether there is a chance for dialogue.

What are we dealing with, when we deal with distrust and threats? Distrust is a subjective category; threat seems to be an objective one. However, strictly speaking we can only talk about threat perceptions. They are usually based on knowledge, such as information on weapon inventories, strategic

1 This article is based on a talk delivered at the International Conference on "Nuclearisation in Europe and the Middle East - From threat to preventive action «, organized by the Swiss sections of the Physicians for Social Responsibility (PSR)/International Physicians for the Prevention of Nuclear War (IPPNW) at Monte Verità, Ascona, Switzerland on 22-25 March, 2007.

* Dr Margret Johannsen, Institute for Peace Research and Security Policy at the University of Hamburg (IFSH). doctrines and war games, and on experience with war, border conflicts, civil strife, terrorism. Yet, even if we base our hypotheses about future risks on real life, we still speculate because we deal not only with capabilities but also with intentions. The nuclear deterrence discourse during the time of the East-West-conflict has taught us that nuclear capabilities without assumed intentions are not considered a threat - this is why the Federal Republic of Germany did not really worry about the nuclear weapons of its French neighbour.

So it is not exactly solid ground that we tread when talking about the intentions of those states we look upon as potential proliferators of nuclear weapons. Why do we believe that a state seeks nuclear weapons because

- it is planning a nuclear strike against another state;

- it wants to be able to attack another state with conventional weapons and feel safe under the umbrella of its own nuclear weapons;

- it is interested in creating problems for another state by supporting liberation movements or terrorism without having to fear military retaliation?

Do we believe that the situation is dangerous because a government says something threatening and we think it is capable of carrying out this threat? Or because it does not say such things but we believe them anyway? Some heads of government talk a lot, some say little, some blunder, by mistake or deliberately - who knows for sure? Do we believe him because we know him or at least think we do? Or because we believe that he is like us? Or do we refuse to believe him because he is so different from us? And because he is so different he must be subjected to a different standard? And is a dialogue at all possible if the credibility of the other is assessed from a position of hegemony?

Uncertainty prevails when we reflect on motives and intentions related to the possession of nuclear weapons. This holds true not only for the Middle East, but has always been the case - notwithstanding the nuclear weapon states' rhetoric during the East-West-conflict about deterrence being the sole purpose of their nuclear arsenals. As long as in the international com- 
munity security and defence are widely considered the exclusive domains of the national state there is no such thing as all - out transparency in military matters. The security dilemma - that states, by providing themselves with military means for their own security, at the same time cause other states to feel insecure and threatened - is a remarkably persistent feature of international relations. Nevertheless, even if we cannot be sure why certain states aspire to attain a nuclear status, we have to take the possible reasons seriously, evaluate them, and judge them without bias. Otherwise, we can forget about dialogue.

\section{Dynamics of proliferation}

Talking about the demand side, we must of course take Israel's nuclear weapons into consideration. The majority of Western analysts assume that Israel considers nuclear weapons as "weapons of last resort" in case the very existence of the Jewish state is at stake. In this sense, they constitute »existential deterrence « against a massive attack employing either conventional weapons or weapons of mass destruction. The deterrent functions of the Israeli nuclear weapons address potential adversaries in the Arab region or the Islamic world and their possible allies. Deterrence in a wider sense includes the function of convincing the Arab world that any attempt to undermine the survival of the Jewish state would be bound to fail, in order to make its Arab neighbours more amenable to a peace that accepts Israel as a legitimate state of the Middle East.

Moreover, its nuclear weapons are said to give the Israeli "client" leverage against its US "patron". In the case of a regional war their very existence could convince friendly nations that, in order to prevent Israel from employing its nuclear weapons, it should receive advanced conventional weaponry.

Furthermore, the guarantee for survival based on nuclear weapons is seen as a tool for increasing the government's domestic manoeuvring space in questions regarding territorial compromise, because nuclear weapons can be seen as counterbalancing a "loss of strategic depth". This function could explain why so-called »doves « in the Israeli Labour Party that argue for giving up occupied territory are at the same time ardent supporters of the nuclear component in Israeli security strategy.

And last but not least, the opposite could also be true. Israel's nuclear weapons could also be seen as allowing Israel to hold on to occupied territory without having to fear another war with the Arab states. This is the view many Arab analysts take, including Mustafa Barghouti whom I quoted at the beginning. This assessment shows that the issue of nuclear proliferation needs to be discussed within the larger framework of crisis and conflict in the Middle East.

When turning to the possible motives of the nuclear havenots to go nuclear two things should be borne in mind: First, they would not be the first to introduce nuclear weapons into the Middle East. Israel's nuclear status could be a reason for them to acquire nuclear status, too. Some call it the »me too « argument, but sneering at it is only evidence of a very short memory. Second, any motive that might be seen as justifying Israel's nuclear option ought, as a matter of principle, not to be discounted as a possible motive for an Arab state or Iran to also develop or acquire nuclear weapons. Arguing otherwise would amount to a bias bordering on nuclear racism as more aggressive rhetoric might put it.

Putting speculation aside, it is safe to say that the Israeli nuclear monopoly is a major factor in the strategic calculations of the regional states. But this does not necessarily imply that every motive for going nuclear is caused by the Israeli nuclear option.

Nuclear weapons can create existential threats to other states. As such they can be used to deter war, for instance by

- threatening to retaliate with nuclear weapons if attacked with weapons of mass destruction;

- threatening to escalate conventional war on non-conventional levels if the enemy is superior in terms of conventional weapons;

- threatening to employ nuclear weapons in case of a military intervention by external powers.

Creating existential threats can also serve other interests than deterring war such as

- forcing the hand of allies or hegemons in order to obtain valuable goods such as high-tech conventional weapons, energy, food etc., including also immaterial goods such as diplomatic relations, security guarantees and the like;

- stimulating arms control;

- increasing the state's status and influence in the region and in the international community;

- increasing the country's prestige in the eyes of the populace and thereby boost the popularity of the regime.

None of these motives applies only to the Middle East. In fact, some of them sound very familiar. In the era of bipolarity, nuclear weapons were looked upon as deterring not only nuclear but also conventional war, thus justifying NATO's firstuse doctrine. The arms control argument was also widely used in the context of East-West-relations. It was part of NATO's dual track decision, which sold the plan to modernise the U.S. land-based intermediate range nuclear weapons (INF) as being instrumental in negotiating away the Soviet SS 20 missiles.

\section{Rationality versus irrationality}

Sometimes it is argued that the situation in the Middle East cannot be likened to the Cold War. This is probably true insofar as on the surface, the bi-polar balance of terror seemed more stable. However, on closer inspection there were areas of lesser and of more security; the credibility of the concept of extended deterrence was sometimes disputed so that the very idea of a "balance" becomes questionable. Another argument is even more problematical. It is based on profound doubts concerning the rationality of the power elites in the Middle East. When discussing whether there is a chance for dialogue this is an important issue, since here seems to be a bias at work 
that suggests a double standard concerning who is entitled to have nuclear weapons and who is not.

All the motives discussed so far are based on a rational calculus. The same is true for the expectation that nuclear weapons can be instrumental in preventing military intervention by external powers. The Iraq war of 1991 has presumably reinforced the urge of regional states to acquire weapons of mass destruction because with the employment of its superior conventional weapons arsenal, the USA impressively demonstrated that any attempt to balance its weapons conventionally is bound to fail. The Iraq war of 2003 has probably underscored this lesson. That a nuclear status can also be used for blackmail has recently been demonstrated by North Korea.

Two motives remain. They are sometimes condescendingly called »glitter effect «. This term applies to the motive of advancing a state's regional and global influence and increasing the regime's popularity. The Egyptian discourse on Egypt's nuclear programme provides a case in point. In theory, Egypt relinquished any intention to develop a strategic nuclear capacity by joining the Treaty on the Non-Proliferation of Nuclear Weapons; for years the call for nuclear disarmament in the Middle East has been a cornerstone of Egyptian diplomacy. However, shortly after India's and Pakistan's nuclear testing in May 1998 Munir Mujahed, in charge of feasibility studies at the Egyptian Nuclear Reactor Authority, likened the effect of a political decision to revive the Egyptian nuclear programme to President Nasser's decision to nationalize the Suez Canal in 1956 that it would revive the spirit and feelings of national pride. Can we safely say that these motives are oriental ones, that they are alien to the enlightened minds of the Americans, the British, the French, the Russians? Or the Chinese, for that matter? As long as there is war, weapons provide status. And being the ultimate weapon, nuclear weapons make a state different from all others except the existing seven nuclear states, whether or not a state confined its stockpiles to a number of warheads deemed sufficient for minimal deterrence. The USA and Russia, in spite of substantial cuts in their inventories, hold firmly to their nuclear status. In fact, they have far more nuclear weapons than they could possibly consider necessary for the purpose of minimal deterrence. The two European nuclear weapon states France and Great Britain resemble them in this respect. The possession of nuclear weapons appears to enhance the role of the nuclear weapon states in the international community, and the apparent influence derived from a nuclear status - be it real or based on self-deception - will not be lost upon other states, neither in the Middle East nor elsewhere.

Thus far nuclear weapons have been discussed as a means to achieve political, economic or diplomatic objectives. I have not discussed the intention to acquire nuclear weapons for the purpose of destroying another state. And I will refrain from discussing this monstrosity - but neither will I argue it away. I only want to point out that assuming such a motive implies construing two classes of states. On the one side, there are those states that consider nuclear weapons to be political weapons useful for advancing one's interests. And on the other side, there are those states that look at nuclear weapons as military weapons to be employed in war and with the purpose of annihilating another state or people. The present discourse on the Iranian nuclear programme and not only the Israeli discourse, sometimes insinuates that this could be the intention of the president of Iran. This insinuation, of course, implies that Iran or its leadership pursue a project that amounts to a nuclear suicide attack. In Israel, this scenario which means annihilation for both the attacker and the defender is labeled the »Samson Option«. It is irrationality carried to the extreme. But the awareness that a nuclear exchange would mean going down together was the core of the balance of terror or the doctrine of mutual assured destruction. If this doctrine has lost its madness, it is because the terms East and West no longer imply political or ideological enmity. The other disputes in Europe with a potential for armed conflict had been settled twenty years before, by means of negotiation and recognition of the territorial status quo.

\section{Regional conflict and nuclear proliferation}

However, the territorial status quo in the Middle East is by no means a foundation on which peaceful coexistence can thrive. For decades, conflicting territorial claims and confrontational security thinking have prevailed in the Arab-Israeli security relations. The mutual threat perceptions are linked to worst-case scenarios, in spite and because of the Middle East peace process which led to peace treaties between Israel and its neighbours Egypt and Jordan, but failed to produce results on the Palestinian, Syrian and Lebanese tracks.

In such a climate of confrontation, it is difficult to convince a state that reaching for the ultimate weapon is not in its selfinterest. There is a hidden nexus between the conflict regarding territory and self-determination on the one hand and the proliferation issue on the other. The link between the two is the profound feelings of insecurity and humiliation that are haunting the Middle East. And here of all regions are we witness to a battle of words which attunes public opinion worldwide to the possibility and legitimacy of preventive military operations - or »anticipatory defence « as the Orwellian phrase goes.

If dialogue is to be given a chance it is essential to tackle the issue of the existential insecurity in the Middle East. Any attempt to bring about a dialogue on the regional problems and crises is bound to fail if and when political leaderships (e.g. in Iran and Syria) have reason to fear they will be forcefully removed from power; if and when democratically elected governments (such as the Palestinian one) do not get the chance to prove themselves; if and when international law is ignored and humanitarian law is violated on a large scale with impunity (as in the Summer Wars of 2006) - in short: if and when the law of the strongest prevails.

There is a perception in the Middle East that in the unresolved regional conflicts it is the law of the strongest that prevails. Fears of annihilation, ethnic cleansing, politicide are poisoning the political discourse and supplying energy for popular feelings of hatred and fear. If this analysis does not fall too short of reality, how do we get from here to dialogue? The 
concept of gradualism has been tried in the Madrid and Oslo processes and has failed. Its supporters in the US administration argued that there is no way to resolve a conflict before the moment of »ripeness « has come. ACRS, the Arms Control and Regional Security Working Group, got bogged down. To be sure, the ACRS exercise was valuable in so far as it generated a discourse between elites that can be seen as an investment hopefully yielding a profit in better times to come. However, time is short not only because this exercise began fifteen years ago and ended ten years ago. The Middle East is a young region. Communities do not live for ever if they are not nursed or cultivated and if no new blood is provided.

\section{Conclusion}

Therefore I would argue for a linkage in tackling these problems, i.e. for a comprehensive approach. It may be true that as long as existential threat perceptions prevail among important regional actors there will not be such a thing as a nuclear free zone. Accordingly, for Israel "comprehensive peace" in the region is a precondition to putting the nuclear issue on the agenda of regional arms control negotiations. At the same time, it would be faulty reasoning to conclude that first the territorial conflicts must be settled, and only then can we begin to seriously tackle the issue of a nuclear weapons free zone. Maybe the opposite is true. For it seems that the taboo concerning the employment of nuclear weapons in an armed conflict is eroding. Therefore it is urgent that negotiations are restarted instead of relying on containment or gunboat policy, instead of hoping that the tactics of tit-for-tat can be pursued forever. As we have recently seen in the Lebanese war, and also in the Gaza Strip: Such tactics may work for a while but never forever. They are communication without words and as such entail a high risk of communicative failure.

Negotiations require conceding the other legitimacy as negotiating partner. If this happens, if a political process at long last replaces the so called low intensity conflict it is time to also launch talks about a nuclear weapons free zone. If there is reason to fear that the next regional war could be waged with weapons of mass destruction, then the settlement of the territorial conflicts that have been festering in the region for decades is of utmost importance to the whole region and beyond. One might raise the objection that there is no territorial dispute between Israel and Iran. That's true. But there is also such a thing as war by proxy, and proxies are not merely puppets on a string, moved at will by their patrons. Under certain conditions they might very well force their patrons' hand. The informal alliances in the Middle East connect the disputes in many ways. Therefore what is needed is a comprehensive approach which puts all the issues on the table. It has been tried before following the first war against Iraq. The negotiations that began in Madrid in October 1991 eventually hit an impasse due to seemingly irreconcilable positions concerning nuclear and territorial issues. After the disaster of the second war against Iraq it is time for lessons to be learned.

\title{
Organisation der OSCE
}

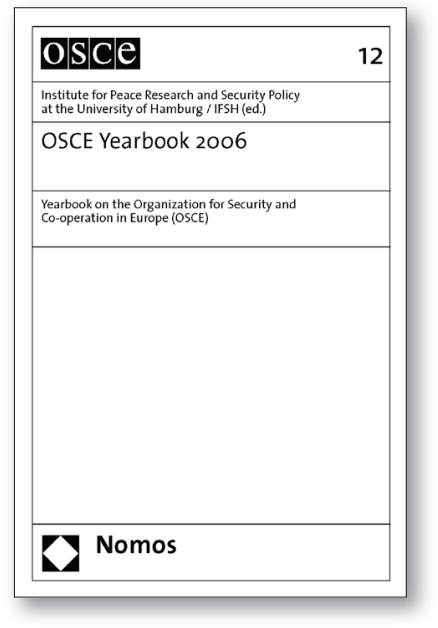

\author{
OSCE Yearbook 2006 \\ Yearbook on the Organization for Security and Co-operation in Europe (OSCE) \\ Vom Institute for Peace Research and Security Policy \\ at the University of Hamburg / IFSH \\ 2007, 482 S., geb., 59,- €, ISBN 978-3-8329-2564-2
}

Das Jahrbuch der Organisation für Sicherheit und Zusammenarbeit in Europa (OSZE) enthält eine Fülle höchst interessanter Aufsätze über die Organisation und ihre Arbeit sowie über die davon betroffenen Themenfelder und Staaten. Ein Schwerpunkt liegt auf der Region um das Schwarze Meer und zeichnet die Entwicklung der Beziehungen mit den Anrainerstaaten nach, ein anderer gibt Einblicke in die Reform der OSZE - insbesondere auch in aktuelle Entwicklungen hinsichtlich der Terrorismusbekämpfung und Polizeireform.

Bitte bestellen Sie bei Ihrer Buchhandlung oder bei Nomos | Telefon 07221/2104-37 | Fax -43 | www.nomos.de | sabine.horn@nomos.de

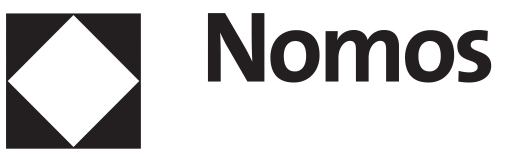

